\title{
Community structure and functional diversity of epiphytic bacteria and planktonic bacteria on submerged macrophytes in Caohai Lake, southwest of China
}

\author{
Dingbo Yan ${ }^{1,2} \cdot$ Pinhua Xia ${ }^{1,2} \cdot \mathrm{Xu}_{\text {Song }}{ }^{1,2} \cdot$ Tao Lin $^{1,2} \cdot$ Haipeng Cao $^{3}$
}

Received: 12 February 2019 / Accepted: 22 May 2019 / Published online: 31 May 2019

(C) Università degli studi di Milano 2019

\begin{abstract}
Purpose Epiphytic bacteria on the surfaces of submerged macrophytes play an important role in lake biodiversity and ecological processes. However, compared with planktonic bacteria, there is poor understanding of the community structure and function of epiphytic bacteria.

Methods Here, we used 16S rRNA gene high-throughput sequencing and functional prediction analysis to explore the structural and functional diversity of epiphytic bacteria and planktonic bacteria of a typical submerged macrophyte (Potamogeton lucens) in Caohai Lake.

Results The results showed that the species composition of epiphytic and planktonic bacteria was highly similar as $88.89 \%$ phyla, $77.21 \%$ genera and $65.78 \%$ OTUs were shared by the two kinds of samples. Proteobacteria and Bacteroidetes were dominant phyla shared by the two kinds of communities. However, there are also some special taxa. Furthermore, the epiphytic bacterial communities exhibited significantly different structures from those in water, and the abundant OTUs had opposite constituents. The explained proportion of the planktonic bacterial community by aquatic environmental parameters is significantly higher than that of epiphytic bacteria, implying that the habitat microenvironment of epiphytic biofilms may be a strong driving force of the epiphytic bacterial community. Functional predictive analysis (Functional Annotation of Prokaryotic Taxa, FAPROTAX) found that epiphytic bacteria and planktonic bacteria are dominated by heterotrophic functions, but epiphytic bacteria have more prominent fermentation and denitrification functions (nitrate reduction, nitrate respiration, and nitrite respiration) than planktonic bacteria.

Conclusion This study has increased our understanding of the communities and functions of epiphytic bacteria on submerged macrophyte leaves, and their role in lake denitrification cannot be ignored.
\end{abstract}

Keywords Epiphytic bacteria $\cdot$ Planktonic bacteria $\cdot$ Diversity pattern $\cdot$ Functional traits

\section{Introduction}

Electronic supplementary material The online version of this article (https://doi.org/10.1007/s13213-019-01485-4) contains supplementary material, which is available to authorized users.

Pinhua Xia

pinhuayy@163.com

1 Guizhou Province Key Laboratory for Information System of Mountainous Areas and Protection of Ecological Environment, Guizhou Normal University, Guiyang 550001, China

2 Plateau Wetland Ecology and Environment Research Center, Guizhou Normal University, Guiyang 550001, China

3 College of Life Sciences, Guizhou Normal University, Guiyang 550001, China
Epiphytic biofilms are widely distributed on solid surfaces such as rocks, sediments, and submerged plants in ponds, rivers, lakes, and marine environments, which harbor a combination of algae, protists, fungi, and bacteria (Palmer Jr. and White 1997; Writer et al. 2011; Lu et al. 2016; Zhao et al. 2018). Biofilms play a major role in regulating the nutrient cycle and energy flow in water bodies, and there is growing research interest in utilizing natural periphytic biofilms in wastewater treatment, nonpoint source pollution control, and remediation of polluted waters (Furey et al. 2016; Singh et al. 2017; Su et al. 2017; Wu et al. 2018). The ecological functions of biofilms are closely linked to the chelation, recycling, or metabolic degradation activities of microorganisms on 
nutrients and pollutants (Wu et al. 2012; Zhao et al. 2018). Therefore, the community structure and ecological functional characteristics of epiphytic biofilm microorganisms are the hotspots of current water ecology research (Wu et al. 2012; Wu et al. 2018). Submerged macrophytes are widely distributed in shallow water ecosystems, and their leaves provide epiphytic areas for the growth of microorganisms and have special niches. However, compared with that of planktonic bacteria, the understanding of the structure and function of epiphytic bacteria on submerged macrophyte leaves is still very limited.

Some previous studies have shown that distinct and shared microorganisms exist between epiphytic and planktonic bacterial communities (Burke et al. 2011; He et al. 2014). Planktonic bacteria have been regarded as a major seed bank for epiphytic bacteria, which has an important influence on the assemblage of epiphytic bacteria (Dolan 2005; Garulera et al. 2016). Certainly, host-specific communities can be selected by complex physical or biochemical characteristics on different plant leaves. Plants and their secretions at different growth stages can also shape the composition of epiphytic bacterial communities (Herrmann et al. 2008; Lachnit et al. 2011; He et al. 2012). Environmental factors also have an important impact on epiphytic bacterial communities, such as $\mathrm{pH}$, redox potential, water flow, light, temperature, and nutrient availability(Bouletreau et al. 2012; Kuehn et al. 2014; Hao et al. 2017). For example, the abundances of Actinobacteria, Nitrospirae, and Verrucomicrobia in biofilms vary with the conductivity of river water, while the presence of Acidobacteria, Gemmatimonadetes, and Proteobacteria in biofilms is associated with $\mathrm{pH}$ changes (Wilhelm et al. 2013; Battin et al. 2016). Similarly, epiphytic bacteria may spread into planktonic bacterial communities (Underwood et al. 2007; Kurian et al. 2012). Clearly, there is a complex interrelationship between epiphytic and planktonic bacteria. However, current reports lack the understanding of the similarities and differences between the structure and function of epiphytic and planktonic bacteria.

Species richness or diversity may not be sufficient to understand how community composition and composition affect ecosystem function (Loreau et al. 2001; Cardinale et al. 2006). This shows that in addition to revealing which microorganisms are in the environment, it is particularly important to determine the functional profile of microbial communities. To this end, researchers have developed a variety of methods based on 16S rRNA high-throughput sequencing to predict bacterial community functions, including the Phylogenetic Investigation of Communities by Reconstruction of Unobserved States (PICRUSt) (Langille et al. 2013), Tax4Fun (Aßhauer et al. 2015), and the Functional Annotation of Prokaryotic Taxa (FAPROTAX) (Louca et al. 2016). Among them, FAPROTAX is the most commonly used method for exploring the biogeochemical cycle functions of microorganisms. It depends on the prokaryotic functional data of culturable bacteria and species classification (OTU table) to obtain community function information, which is applicable to a variety of environmental samples and has the advantages of reliable results and economical and practical benefits (Louca et al. 2016; Galand et al. 2018). This provides an effective solution for understanding the differences in the structure and function of epiphytic and planktonic bacterial communities.

This study focuses on the typical macrophytic lake (Caohai) in southwest China and compares the structure and function of epiphytic and planktonic bacteria by $16 \mathrm{~S}$ rRNA gene high-throughput sequencing and functional predictive analysis. The study aims to address the following three topics: (i) characteristics of epiphytic and planktonic bacterial community species composition, (ii) community structure of epiphytic and planktonic bacteria and their relationship with the environment, and (iii) epiphytic bacterial community function and its environmental significance.

\section{Material and methods}

\section{Study site and sampling}

The sampling sites were located in the karst area of southwest China, Caohai National Nature Reserve $\left(104^{\circ} 12^{\prime}-104^{\circ} 18^{\prime} \mathrm{E}\right.$, $26^{\circ} 49^{\prime}-26^{\circ} 53^{\prime} \mathrm{N}$ ) with a subtropical semi-humid monsoon climate. With a water area of $25 \mathrm{~km}^{2}$ and an average temperature of $10.5^{\circ} \mathrm{C}$, it is one of the three highest plateau freshwater lakes in China (2171 m above sea level). It is a typical macrophytic lake ecosystem with abundant aquatic vegetation and a water depth of approximately $3 \mathrm{~m}$. Samples were gathered from 9 sites on the lake in November 2017 (Fig. 1). Weining County is at the northeast region of the lake, where a large amount of domestic sewage enters the protected area (S1, S2, S3, and S4, named HP), and has relatively heavy pollution. The southwestern part of the lake has less pollution (S5, S6, S7, S8, and S9, named LP). Submerged macrophytes (Potamogeton lucens) were collected with a hook that was cleared with in situ water. Approximately $10 \mathrm{~g}$ of freshweight leaf samples was cut away from three to five plant replicates and transferred into a sterile $500-\mathrm{mL}$ polyethylene bottle containing $400 \mathrm{~mL}$ of $50 \mathrm{mM}$ phosphate-buffered saline (PBS, $\mathrm{pH}=7.4$ ) solution for epiphytic bacterial community analysis (Zhang et al. 2016). In addition to plant sampling, 1.5-L water samples from the area surrounding the sampling area for physicochemical and planktonic bacterial community analysis were collected. All leaf samples were collected in three replicates, mixed, kept with ice bags, and quickly returned to the laboratory. Dissolved oxygen and $\mathrm{pH}$ were determined using a portable instrument $(\mathrm{HQ} 30 \mathrm{~d}, \mathrm{HACH}$, USA). The physicochemical properties of the water column 


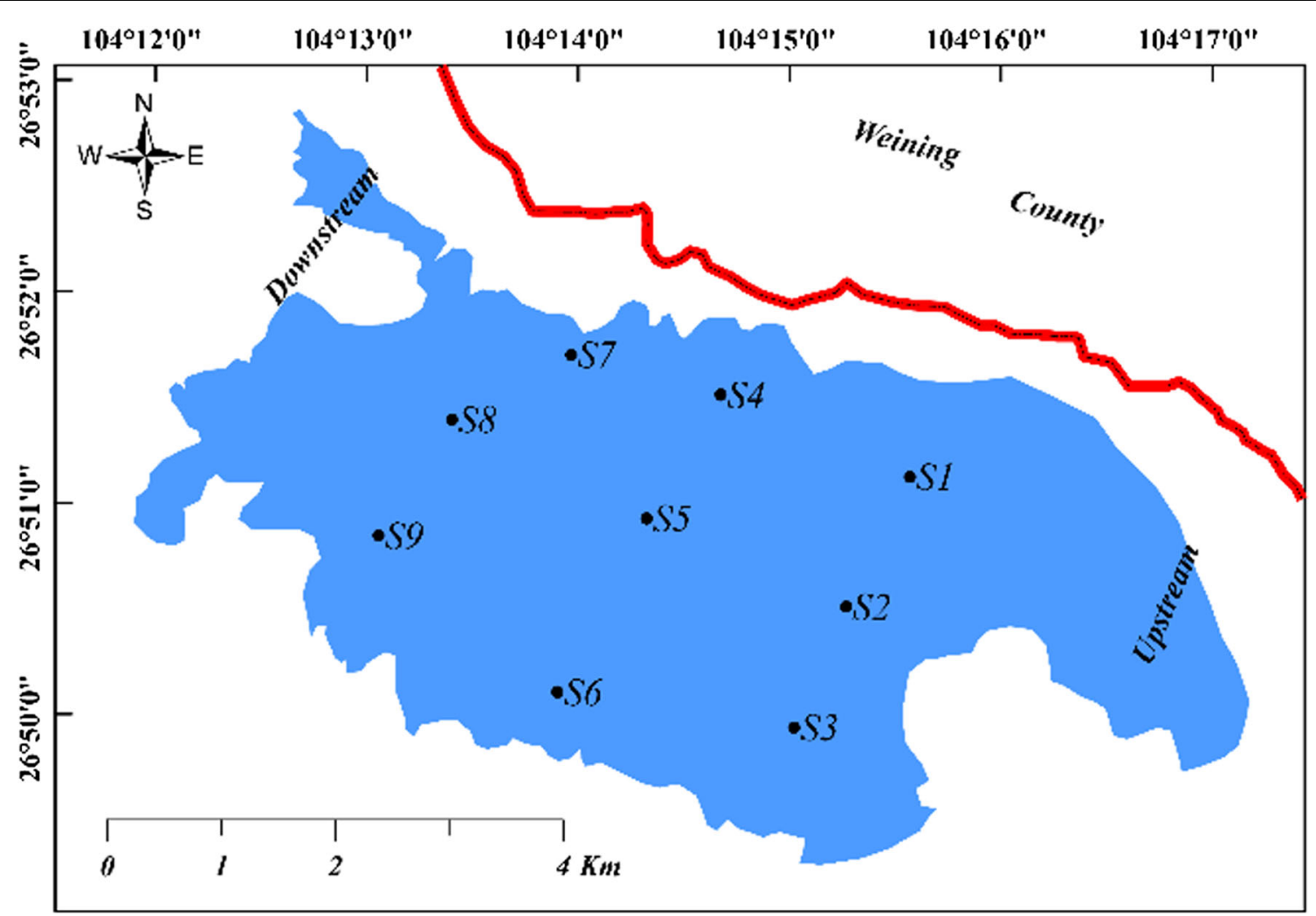

Fig. 1 Map of Caohai lake, Guizhou, showing the location of the sampling sites. Meanwhile, the main submerged plant is Potamogeton lucens during the season of our sampling period

were determined according to standard methods for the surface water of China (GB3838-2002). Total nitrogen was assayed using alkaline persulfate digestion and UV spectrophotometry (UV mini-1240, Shimadzu, Japan). Total phosphorus was determined with acidified molybdate to form reduced phosphor-molybdenum blue, which was measured spectrophotometrically. Ammonia nitrogen was measured using a spectrophotometric method with Nessler's reagent, chemical oxygen demand was measured using the potassium permanganate index method, and the chlorophyll a concentration was estimated spectrophotometrically after extraction in $90 \%$ ethanol.

\section{Sample pretreatment and sequencing}

Epiphytic bacteria were detached after 3 min of ultrasonication (KQ5200DE, Kunshan, China), $30 \mathrm{~min}$ of shaking (225 r/min) (SHZ-82A, Changzhou, China), and subsequent ultrasonication for $3 \mathrm{~min}$. After complete detachment, $100 \mathrm{~mL}$ of mixed liquor was filtered through $0.22-\mu \mathrm{m}$ membrane filters (Millipore Ireland Ltd., Ireland) to collect epiphytic bacteria. Planktonic bacteria were collected by filtering $500-\mathrm{mL}$ water samples through $0.22-\mu \mathrm{m}$ membrane filters. Then, all filters were stored at $-20^{\circ} \mathrm{C}$ before bacterial DNA extraction (He et al. 2012). Extraction of bacterial DNA was performed according to the instructions of the FastDNA ${ }^{\circledR}$
Spin Kit for Soil (MP, USA), DNA concentration and purity were detected using a NanoDrop 2000 (Thermo Fisher Scientific, USA), and DNA quality was checked by $1 \%$ agarose gel electrophoresis. The V3-V4 hypervariable regions of the bacteria $16 \mathrm{~S}$ rRNA gene were amplified using the primers 338F (5'-ACTCCTACGGGAGGCAGCAG-3') and 806R (5'GGACTACHVGGGTWTCTAAT-3') (Xu et al. 2016). The PCRs were performed in a $20-\mu \mathrm{L}$ reaction mixture containing $4 \mu \mathrm{L}$ of $5 \times$ FastPfu Buffer, $2 \mu \mathrm{L}$ of $2.5 \mathrm{mM}$ dNTPs, $0.8 \mu \mathrm{L}$ of each primer $(5 \mu \mathrm{m}), 0.4 \mu \mathrm{L}$ of FastPfu Polymerase, $10 \mathrm{ng}$ of template DNA, and $\mathrm{ddH}_{2} \mathrm{O}$ up to $20 \mu \mathrm{L}$. The amplification program included an initial denaturation step at $95{ }^{\circ} \mathrm{C}$ for $3 \mathrm{~min}$, followed by 25 cycles at $95^{\circ} \mathrm{C}$ for $30 \mathrm{~s}$ (denaturation), $55^{\circ} \mathrm{C}$ for $30 \mathrm{~s}$ (annealing), and $72^{\circ} \mathrm{C}$ for $30 \mathrm{~s}$ (extension), with a final extension at $72{ }^{\circ} \mathrm{C}$ for $5 \mathrm{~min}$ (Mori et al. 2013), using $2 \%$ agarose gel to recover PCR products; purification using AxyPrep DNA Gel Extraction Kit (Axygen Biosciences, Union City, CA, USA) with Tris-HCl elution was performed. Quantitative detection using QuantiFluor ${ }^{\text {TM}}$-ST (Promega, Madison, WI, USA) and sequencing using Illumina's MiSeq PE300 platform (Illumina, San Diego, USA) were performed. The raw sequences were quality-filtered by Trimmomatic and merged by FLASH (http://ccb.jhu.edu/software/FLASH/). Operational taxonomic units (OTUs) were clustered using 97\% similarity cut-off with UPARSE version 7.1 (http:// drive5.com/uparse/) with a novel "greedy" algorithm that 
performs chimera filtering and OTU clustering simultaneously. The taxonomy of each 16S rRNA gene sequence was analyzed by the RDP Classifier algorithm (http://rdp.cme.msu.edu/) against the Silva (SSU128) 16S rRNA database using a confidence threshold of $70 \%$ (Cole et al. 2014). Then, sequences were subsampled at $27353 \mathrm{bp}$ (sample minimum sequence length). In addition, alpha diversity matrix was calculated by Mothur (version 1.30.1) based on the OTU level.

\section{Data analysis and functional predication}

The sampling diagram was drawn using ArcGIS (version 10.5). Information was analyzed with different approaches. The distinction of alpha diversity between the two types of sample compared by analysis of variance (ANOVA). Data visualization was performed using $\mathrm{R}$ (version 3.4.3, https:// www.r-project.org/). Boxplots were drawn by "ggplot2" for visualization of the physical-chemical properties of water and the bacterial alpha diversity index. The "pheatmap" package was applied to display the relative abundances of OTUs across different sample sites. Nonmetric multidimensional scaling analysis (NMDS) and the ANOSIM test based on BrayCurtis distance were used to calculate the beta diversity matrix by the "vegan" package. Redundancy discriminant analysis (RDA) was performed using the vegan package. Linear discriminant analysis (LDA) effect size (LEfSe) was generated from Python (version 2.7) to estimate which microbiome attributes differ significantly between the two types of communities. Differences were evaluated via Kruskal-Wallis and Wilcoxon rank-sum testing, with an alpha value of 0.05 for the factorial Kruskal-Wallis test among classes and pairwise Wilcoxon rank-sum test between subclasses and a threshold for the logarithmic linear discriminant analysis score for discriminate features of 4.0 .

To further analyze the biogeochemical cycle functions of microorganisms, we also applied FAPROTAX (version 1.1). FAPROTAX is a manually constructed database that maps prokaryotic taxa (e.g., genera or species) to metabolic or other ecologically relevant functions (e.g., nitrification, denitrification, or fermentation) based on the literature of cultured representatives. Functions represented in FAPROTAX focus on marine and lake biogeochemistry, and the program includes a Python script for converting OTU tables into putative functional tables based on the taxa identified in a sample and their functional annotations in the FAPROTAX database. One weakness of applying this approach to our data is the implicit assumption of FAPROTAX that if all cultured members of a taxon (cultured and noncultured) can perform that function, then all members of the taxon (cultured and noncultured) can perform that function (Louca et al. 2016; Kumar et al. 2018). Even considering this limitation, we believe that predicting putative functional groups using this approach is superior to genomic prediction approaches based on sequence homology (Louca et al. 2016; Kumar et al. 2018). Differences in functional profiles between the two groups were compared via the Wilcoxon rank-sum test using the Statistical Analysis of Metagenomic Profiles (STAMP v2.1.3, http://kiwi.cs.dal.ca/ Software/STAMP) software (Parks et al. 2014).

\section{Result}

\section{Physical-chemical characteristics of the water column}

The physical-chemical properties of the water column displayed clear distinctions between HP and LP (Fig. S1). The $\mathrm{pH}$ of the water column ranges from 8.32 to 9.47 and generally presented as weakly alkaline, with the highest at S6 of 9.47 and the lowest at S2 of 8.32. The ammonia nitrogen concentrations in the HP and LP areas were 0.356$0.716 \mathrm{mg} \mathrm{L}^{-1}$ and $0.338-0.393 \mathrm{mg} \mathrm{L}^{-1}$, respectively (ANOVA, $p<0.05$ ). The total nitrogen values were $0.676-$ $0.952 \mathrm{mg} \mathrm{L}^{-1}$ in the HP areas and $0.418-0.587 \mathrm{mg} \mathrm{L}^{-1}$ in the LP areas $(p<0.05)$. The chemical oxygen demand values were 7.35-8.05 $\mathrm{mg} \mathrm{L}^{-1}$ (HP) and 5.54-7.20 $\mathrm{mg} \mathrm{L}^{-1}$ (LP) $(p<0.05)$. The water quality of the sampling point was evaluated by the Carlson comprehensive nutrition index method, and the weights were calculated by four parameters: chemical oxygen demand, levels of chlorophyll a, total nitrogen, and total phosphorus. The results showed that the comprehensive eutrophication index (TLI) of Caohai Lake ranged from 26.61 to 38.75 ; the maximum appeared in the S1 sample, the average in the HP region was 36.17 , and the average in the LP region was 31.75 . The difference in the eutrophication index between the two regions was significant (ANOVA: $p=0.044$ ).

\section{Description of overall sequences}

Subsamples normalized to the smallest sample sequence length (27,353 bp) are from 1,089,908 total high-quality sequences (with $443.89 \pm 46.27$ bp of average length, mean \pm SD), which were binned into 976 OTUs based on 97\% similarity. Phylogenetic classification results showed a total of 27 microbial phyla in all samples, including 59 classes, 115 orders, 204 families, 373 genera, 560 species, and many unclassified species $(67.80 \%)$. Among the identified taxonomic groups of all samples, $88.89 \%$ phyla, $81.36 \%$ classes, $79.13 \%$ orders, $78.43 \%$ families, and $77.21 \%$ genera were shared by epiphytic bacteria and planktonic bacteria (Table S1). At the phylum level, Proteobacteria and Bacteroidetes were the most shared groups for epiphytic and planktonic bacteria, Nitrospirae and SR1_Acondconditabacteria were distinct species in epiphytic bacterial communities (EBC), and Peregrinibacteria is a unique component of the planktonic bacterial community (PBC). The relative number of Proteobacteria in the EBC 
was as high as $65.83 \pm 9.13 \%$ (mean $\pm \mathrm{SD}, N=9$ ), but only $41.98 \pm 6.82 \%$ in the PBC. Bacteroidetes in both communities were maintained at approximately $20 \%$. The Actinobacteria in the EBC accounted for only $0.43 \pm 0.27 \%$, while those in the $\mathrm{PBC}$ were up to $20.11 \pm 9.36 \%$. Compared with EBC, the proportion of Verrucomicrobia and Cyanobacteria in the PBC increased $(0.28 \pm 0.22 \%$ vs $6.83 \pm 3.81 \%$ (EBC vs PBC), $2.14 \pm 1.72 \%$ vs $5.46 \pm 5.67 \%$ respectively). Likewise, the largest decrease in the PBC was that of the Firmicutes, which decreased from $11.32 \pm 7.62 \%$ in the $\mathrm{EBC}$ to $0.63 \pm 1.05 \%$ in the PBC (Fig. 2a). This indicates that although the EBC and PBC share many different classification levels, the relative quantity distribution of the different groups varies greatly.

\section{Significant differences in alpha and beta diversity between epiphytic and planktonic communities}

The alpha diversities of epiphytic and planktonic bacterial communities were compared according to OTU (at 3\% cut-off) levels. The Shannon indices ranged from 2.51 to 3.50 (EBC) and 3.36 to 4.57 (PBC) (ANOVA: $p<0.001$ ). Moreover, the OTU richness Chaol indices ranged from 410 to 577 (EBC) and 465 to 595 (PBC) $(p<0.05)$. The Shannon evenness indices ranged from 0.427 to 0.569 (EBC) and 0.570 to 0.720 (PBC) $(p<0.001)$. The phylogenetic diversity (PD) ranged from 25.64 to 46.67 (EBC) and 37.16 to 49.77 (PBC) $(p<0.01)$. We found that the alpha diversity of the EBC was significantly lower than that of the PBC (Fig. 2b). The OTU numbers of the EBC and $\mathrm{PBC}$ were $334.6 \pm 73.83$ vs $432.66 \pm 45.71$; the $\mathrm{PBC}$ 's richer
OTU composition confirms its high alpha diversity. Likewise, at the genus level, the relative abundance less than $1 \%$ of the phytoplanktonic bacterial communities increased to $23 \%$ vs $8.7 \%$ of the epiphytic bacteria, further confirming the high alpha diversity of the planktonic bacterial community.

Although the OTUs shared by EBC and $\mathrm{PBC}$ reached $65.78 \%$, the dominant OTUs were markedly different in the two sample types (Fig. S2). Relatively abundant species (except Flavobacterium) of each other showed a significant inverse relationship, and the abundant species in one group were at a lower abundance level in the other group. The dominant genera ( $>5 \%$ of total reads) in the EBC were Pseudomonas (mean value $43 \%$, $N=9)$, Flavobacterium (11\%), Chryseobacterium (8.9\%), and Exiguobacterium (7.4\%). In contrast, Flavobacterium (13\%), hgcI_clade (9.1\%), Acinetobacter (7\%), and Limnohabitans (7\%) were abundant in the PBC. To further reveal the difference between EBC and PBC species composition, an NMDS analysis based on Bray-Curtis distances was performed according to the OTU distribution (Fig. 3). The epiphytic bacterial samples were clearly separated from planktonic bacterial samples (stress = 0.056), and an ANOSIM test based on Bray-Curtis similarity distances further confirmed the separation between epiphytic and planktonic bacterial communities $(R=0.9979, p=0.001)$. To further define differences, LEfse analysis at the phylum to genus level uncovered the great difference in taxonomic units between EBC and PBC (Fig. 4). There are 8 differential indicator species at the genus level for epiphytic bacteria: Pseudomonas, Aeromonas, Janthinobacterium, Rahnella, unclassified_f_Enterobacteriaceae (Proteobacteria),
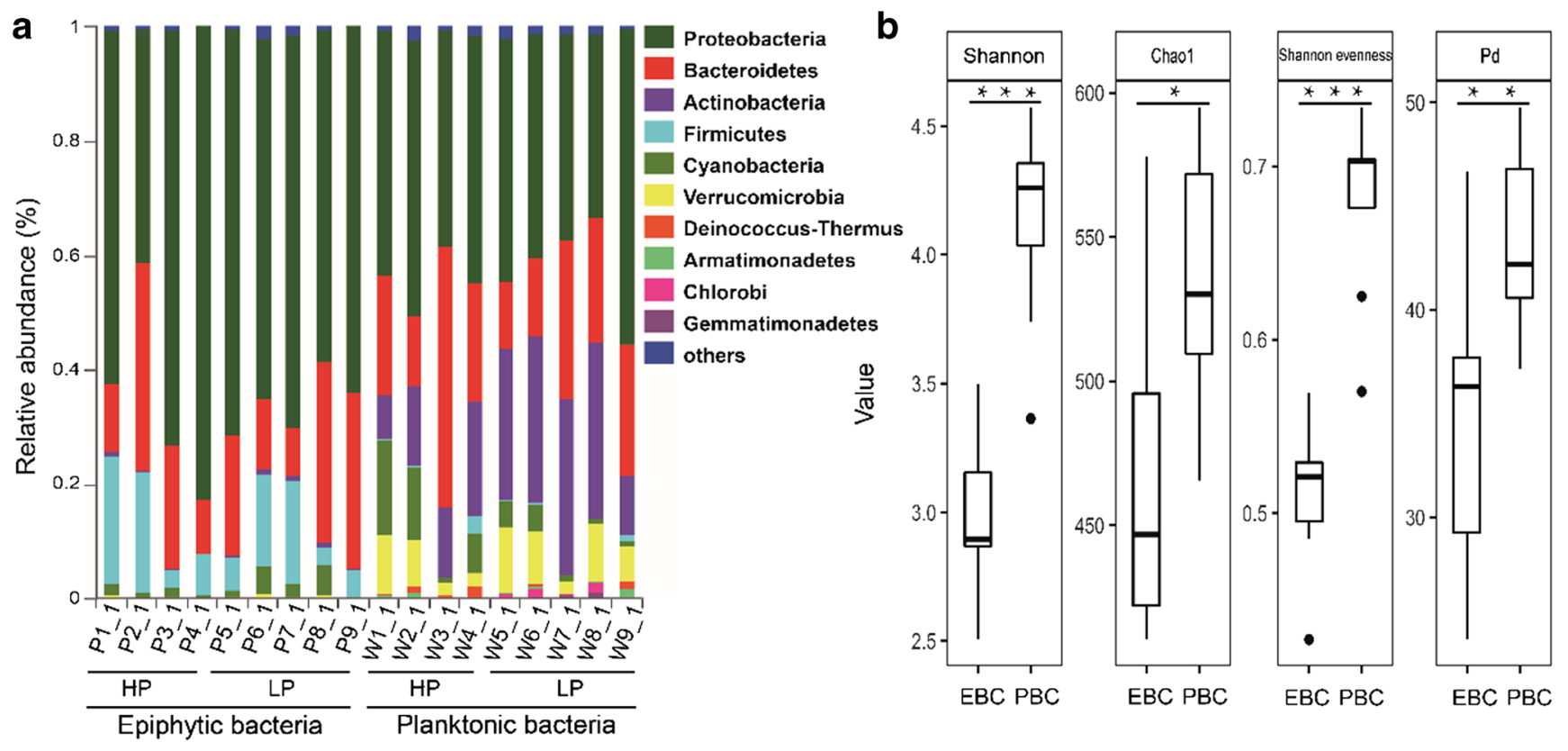

Fig. 2 a The percent of community abundance on phylum level in the two kinds of samples. EBC: epiphytic bacterial community, PBC: planktonic bacterial community. HP (heavy pollution): S1, S2, S3, and S4. LP (light pollution): S5, S6, S7, S8, and S9. Only groups' percentage

over 0.01 of all samples were displayed; the lower were pooled together and referred to as "other". b The alpha diversity on the OTU level of bacterial communities. DP: phylogenetic diversity. ${ }^{*} p<0.05,{ }^{* *} p<0.01$, ${ }^{* * * *} p<0.001$ 
Fig. 3 NMDS similarities between all samples. The planktonic samples were clustered far apart from the epiphytic samples. ANOSIM test indicated great distinction between the two kinds of samples $(R=0.9979, p=0.001)$. HP (heavy pollution): $\mathrm{S} 1, \mathrm{~S} 2, \mathrm{~S} 3$, and S4. LP (light pollution): S5, S6, S7, S8, and S9

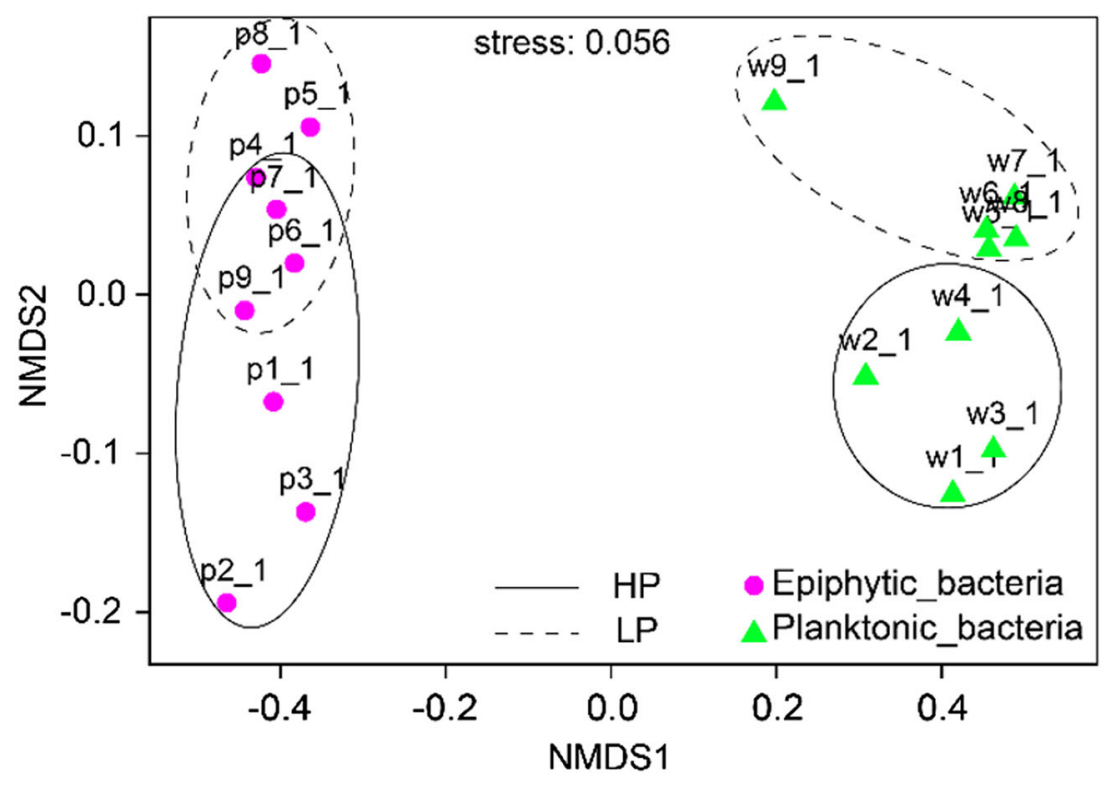

Trichococcus, Exiguobacterium (Firmicutes), and Chryseobacterium (Bacteroidetes). The 10 differential indicator species at the genus level for planktonic bacteria were Methylocystis, Limnohabitans, Brevundimonas, Acinetobacter, Polynucleobacter, norank_f_Sphingomonadaceae (Proteobacteria), hgcI_clade, Mycobacterium, CL50029 marine_group (Actinobacteria), and Synechococcus (Cyanobacteria).

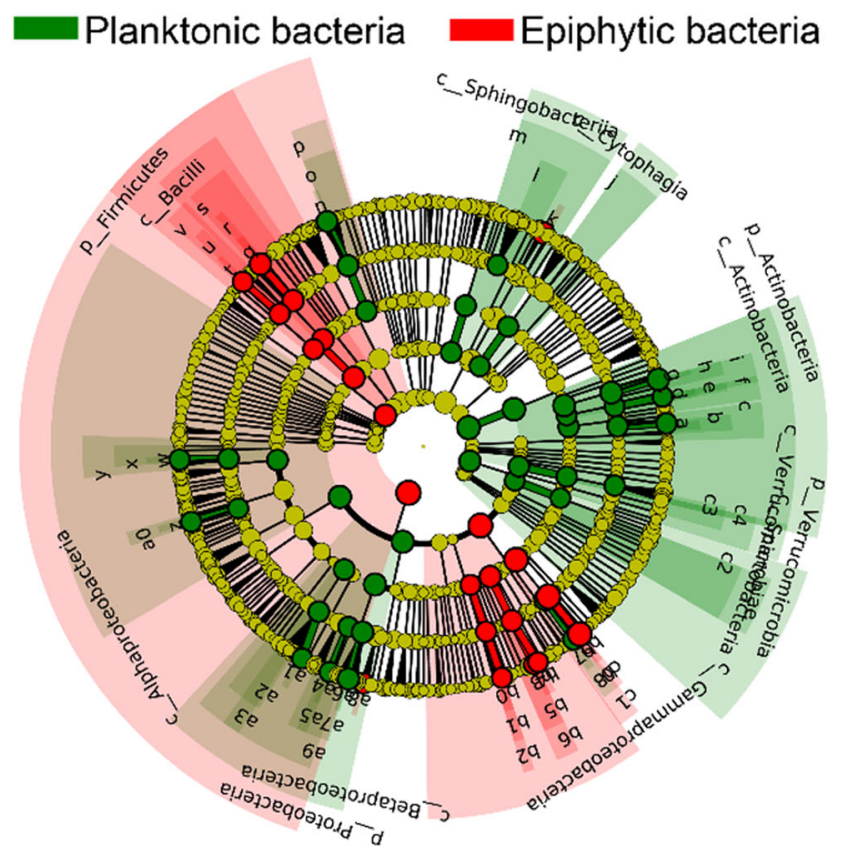

Fig. 4 Taxonomic cladogram comparing all samples categorized in the two groups by least discriminant analysis (LDA) effect size (LDA $>4$, $p<0.05$ ) and applied all-against-all (more strict) comparative strategy. The innermost circle represents the phylum taxonomy level, and the outer circle in turn represents the taxonomy level of class, order, family, and genus. The size of the node represents the abundance, significantly

\section{Relationship between bacterial communities and environmental factors}

Using RDA to link bacterial community variations with environmental parameters could also explain bacterial beta diversity. According to variance inflation factors (VIF), less than 10 environmental parameters were selected by the forward selection principle, eliminating chlorophyll a. In our results (Fig. 5), there

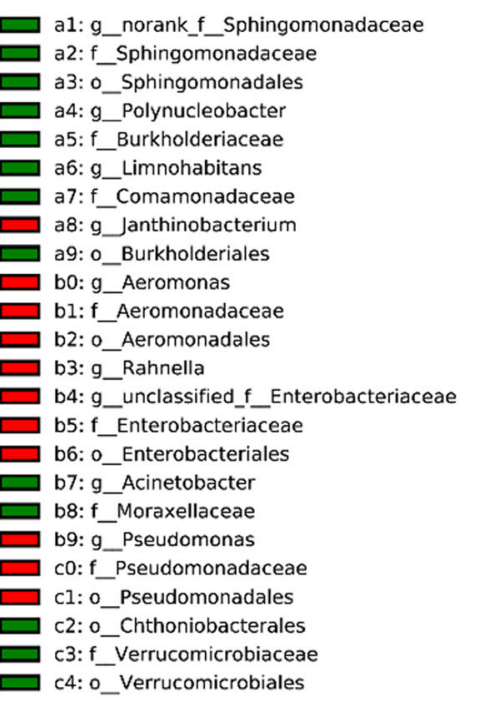

$\square$ a: g_CL500_29_marine_group $\square$ b: f_Acidimicrobiaceae $\square$ c: o_Acidimicrobiales

$\square$ d: g_Mycobacterium

$\square$ e: f_Mycobacteriaceae

$\square$ f: o_Corynebacteriales

g: g_hgcl_clade

$\square$ h: f_Sporichthyaceae

$\square$ i: o_frankiales

$\square$ j: o_Cytophagales

k: g_Chryseobacterium

I:f_Chitinophagaceae

m: o_Sphingobacteriales

n: g_Synechococcus

o:f_Familyl_o_Subsectionl

$\square$ p: 0 Subsection।

q: g_Exiguobacterium

$\square$ r: f_Family_XII_o_Bacillales

s: o_Bacillales

$\square$ t: g_Trichococcus

$\square$ u:f_Carnobacteriaceae

$\square$ v: o_Lactobacillales

$\square$ w: g_Brevundimonas

x:f_Caulobacteraceae

y: o_Caulobacterales

z: g_Methylocystis

$\square$ a0: f_Methylocystaceae discriminant taxon nodes were colored, and the branch areas are shaded according to the highest ranked group for that taxon. When the taxon was not significantly differentially represented among the sample groups, the corresponding node was colored yellow. Highly abundant and selected taxa are indicated 


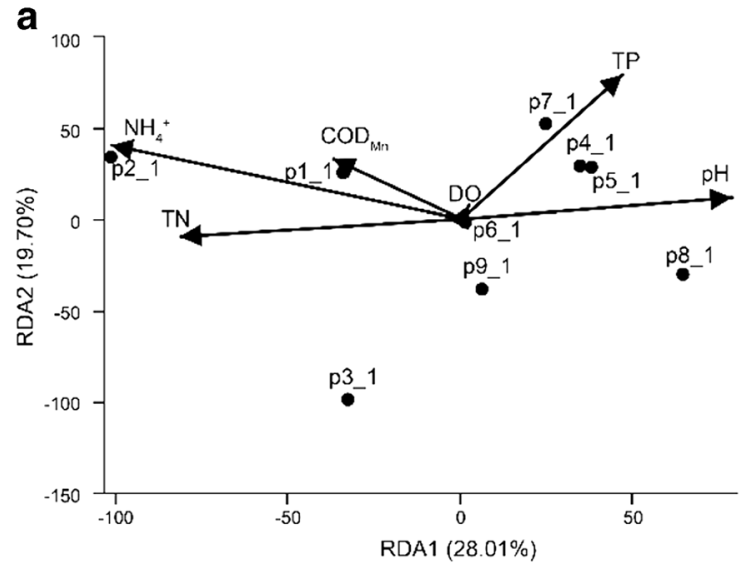

Fig. 5 RDA analysis ordination diagram of environment factors related to bacterial phylogenetic groups at the OTU level. The arrow length and direction correspond to the variance that can be explained by the environmental and response variables. The direction of an arrow indicates the extent to which the given factor is influenced by each RDA variable. The perpendicular distance between the sample sites and

is a close interaction between the bacterial community and the water quality, but the two communities respond differently to water quality. Chemical oxygen demand $\left(R^{2}=0.808, p=\right.$ $0.037)$ and total phosphorus $\left(R^{2}=0.604, p=0.015\right)$ were significantly associated with planktonic bacteria variations, while changes in epiphytic bacteria can be well explained by ammonia nitrogen $\left(R^{2}=0.817, p=0.011\right)$, total phosphorus $\left(R^{2}=0.604\right.$, $p=0.073), \mathrm{pH}$, and total nitrogen. All selected parameters on the first two axes explained $47.71 \%$ (EBC) and $60.34 \%$ (PBC) of the bacterial community changes, suggesting that the complex microenvironment in the biofilms of submerged macrophytes drives the differences between the epiphytic and planktonic community structures.

\section{Functional traits of epiphytic and planktonic bacterial communities}

A number of microorganisms are involved in crucial biogeochemical processes and interspecies interactions. The putative functions of FAPROTAX are mainly used to further analyze the functions of biogeochemical cycles of microorganisms, especially the circulatory functions of sulfur, carbon, hydrogen, and nitrogen. Among the putative functions, a total of 48 putative biogeochemical cycle functions were identified from the epiphytic community and planktonic community. Although the most common functions of epiphytic and planktonic communities were chemoheterotrophy and aerobic chemoheterotrophy, there was a significant gene abundance difference between the two community types $(p<0.01)$ (Fig. 6). Chemoheterotrophy and aerobic chemoheterotrophy were mainly contributed by the abundant bacteria such as Acidobacteria, Flavobacteria, Proteobacteria, and

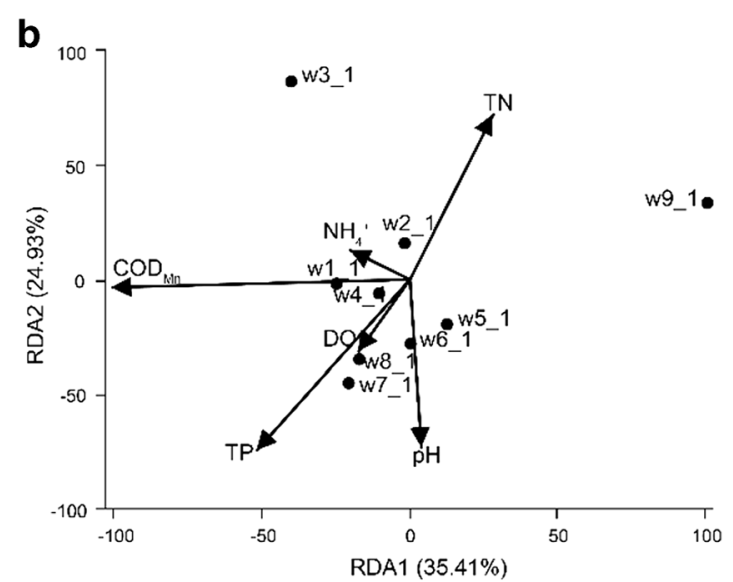

environmental variable axes in the plot reflects their correlations. The smaller the distance, the stronger the correlation. a RDA analysis of epiphytic bacteria. b RDA analysis of planktonic bacteria. DO: dissolved oxygen, TN: total nitrogen, TP: total phosphorus, $\mathrm{NH}_{4}{ }^{+}$: ammonia nitrogen, $\mathrm{COD}_{\mathrm{Mn}}$ : chemical oxygen demand

Verrucomicrobia. The special biogeochemical functions in EBC were the fermentation and nitrogen cycle (especially denitrification), which included nitrate reduction, nitrate respiration, nitrogen respiration, nitrite respiration, nitrate ammonification, and nitrite ammonification. PBC is rich in autotrophic functions (phototrophy, photoautotrophy, oxygenic photoautotrophy) in animal parasites or symbionts, human pathogens all, aromatic compound degradation, methylotrophy, and hydrocarbon degradation.

\section{Discussion}

\section{Species characteristics of epiphytic and planktonic bacterial communities}

We found that the two kinds of environmental species have a higher rate of shared feature, which may be because planktonic bacteria are the main seed bank of epiphytic bacteria (Dolan 2005; Garulera et al. 2016), such as Flavobacterium, Sphingomonadaceae, Caulobacteraceae, and Moraxellaceae. They may be versatile in adapting to different kinds of habitats and represent the intercommunication of epiphytic bacteria and planktonic communities. However, our results indicated that both epiphytic and planktonic bacteria have specific microbial groups and that the community structures are significantly different.

There are obvious differences in structure between epiphytic and planktonic bacterial communities (Figs. 3 and 4 and S2). This result is consistent with studies of Potamogeton crispus and Wolffia australiana leaf epiphytic bacteria in freshwater (He et al. 2014; Xie et al. 2015). The most abundant OTUs of 
Fig. 6 Putative functions of samples only displayed the significant difference between epiphytic and planktonic communities in Wilcoxon ranksum test. The left panel displayed the abundance ratio of different functional groups; the middle showed the percentage of functional group abundance within the 95\% confidence interval; the right ${ }^{*} p<0.05,{ }^{* *} p<0.01$, and $p<0.001$

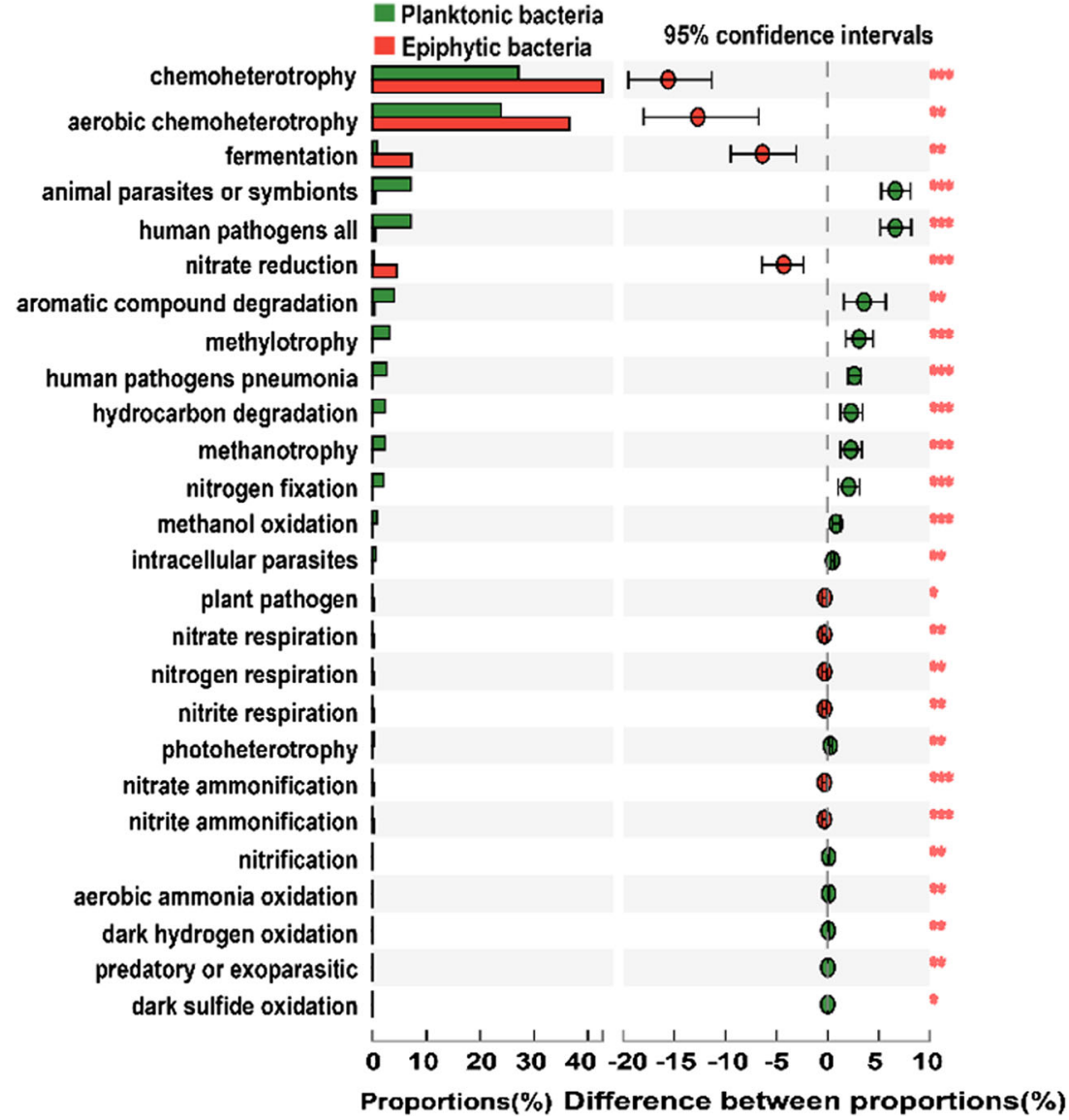

epiphytic bacteria were affiliated with Pseudomonas (Fig. S2), a genus that demonstrates substantial metabolic diversity and consequently is able to colonize a wide range of niches (Michael et al. 2005). Pseudomonas usually have one or more flagella to improve mobility and adhesion and can also produce a large number of extracellular polysaccharides related to biofilm formation (Hassett et al. 2002). Another abundant OTU in the epiphytic bacterial community was affiliated with Chryseobacterium; species in this genus can adapt to diverse habitats and have the ability to inhibit phytopathogenic fungi (Matu et al. 2019). Exiguobacterium and Janthinobacterium are important contributors to epiphytic community specificity (Fig. 4). They are able to withstand many environmental stresses (wide range of $\mathrm{pH}$, cold, UV, etc.), can metabolize many types of substrates, and have strong viability (Ordoñez et al. 2013; Koo et al. 2016). Specific and abundant OTUs in the planktonic bacterial community were affiliated with $\mathrm{Hgcl}$-clade, Acinetobacter, Limnohabitans, Synechococcus, and Polynucleobacter. These taxa are typical and dominant bacterioplankton taxa in freshwater columns, as some taxa need a strictly aerobic environment, sufficient light, etc. (Jezberová et al. 2010; Bitrian et al. 2013; Kasalický et al. 2013). They may be specialists for water columns and lack the capacity to live in certain interfaces, such as the leaf surfaces of submerged macrophytes.

\section{Environmental regulation of epiphytic bacteria and planktonic bacteria communities}

So far, there are only a few studies on the differences between epiphytic and planktonic bacterial communities. The alpha diversity of the epiphytic bacterial community on Potamogeton crispus leaves was significantly higher than that of the planktonic bacterial community (He et al. 2014). However, Bengtsson et al. (2012) and Xie et al. (2015) showed that the alpha diversity of epiphytic bacterial communities is significantly lower than that of planktonic bacterial communities. In this study, the alpha diversity of the epiphytic bacterial community on Potamogeton lucens leaves was significantly lower than that of the planktonic bacterial community $(p<0.05)$ (Fig. 2), and there were significant differences between epiphytic bacteria and planktonic bacteria communities (Fig. 3). Habitat type (microenvironmental) and aquatic environmental factors were the dominant factors driving the difference.

NMDS analysis showed that the compositions of bacterial communities were more similar within similar habitat samples (Fig. 3), strongly suggesting that a habitat microenvironment "stress filter" was involved in the compositional structuring on the leaves of submerged plants. For 
example, the circadian rhythm of plants formed distinct day and night dissolved oxygen concentrations, unique products, and secretions (special carbon sources) on the surfaces of submerged plant leaves, and respiration of epiphytic algae led to an increase in the $\mathrm{pH}$ of the biofilm, the physical barrier of biofilm extracellular polymer (EPS) (dispersal limitation), and biological interactions (symbiosis and hostility) driving the two kinds of habitat-related bacteria distinction (Paul and Pohnert 2011; Song et al. 2015; Liu et al. 2016; Florez et al. 2017; Seymour et al. 2017). Therefore, habitat microenvironment-based species sorting is suggested as a key factor in determining bacterial community structures in aquatic environments (Filippini et al. 2009; Jones and McMahon 2009). In addition, there also exist differences in bacterial composition between HP and LP in each kind of sample, suggesting that factors other than habitat type also participate in the regulation of epiphytic and planktonic bacterial dynamics.

Physicochemical properties of the surrounding water column were critical drivers of variation observed in the epiphytic bacterial communities (Fig. 5). Epiphytic bacterial communities on Potamogeton lucens leaves were modulated significantly by concentrations of ammonia nitrogen and total nitrogen, implying that an increase in nitrogen nutrition can considerably influence the microbiology associated with submerged macrophytes (Yan et al. 2018). Increasing ammonia nitrogen levels can change the composition and content of submerged plant secretions, thus influencing the community structure of epiphytic bacteria (Cao et al. 2004). Total phosphorus is another important factor affecting the epiphytic community structure found on Potamogeton lucens. $\mathrm{pH}$ was a strong driving force of epiphytic bacterial communities on Potamogeton lucens leaves, as found in various environments (Hörnström 2002). Other factors, such as temperature, light intensity, and nutrient availability, are also important factors that influence epiphytic bacterial community structure (Bing et al. 2018; Zhao et al. 2018). This study only captured a small subset of physicochemical factors, which may lead to a lower explained proportion of environmental factors for epiphytic and planktonic bacterial community changes. Similarly, our results may be onesided, because our sample size is low (although we collected three repetitions for each sample), and there are inherent errors in the core processes such as PCR preferences. Aquatic environmental factors cannot fully explain the variances in the epiphytic bacterial community (the explained proportion was only $47.71 \%$ by the first two axes), further demonstrating the important role of the habitat microenvironment (epiphytic biofilm) in the construction of epiphytic bacterial communities. This effect (the habitat microenvironment "stress filter") may be an important reason for the alpha diversity of epiphytic bacterial communities to be lower than that of planktonic bacteria.

\section{The epiphytic bacterial community of submerged macrophytes has important denitrification functions}

The most abundant biogeochemical cycle functions of epiphytic and planktonic bacterial communities were chemoheterotrophy and aerobic chemoheterotrophy (Fig. 6). Heterotrophic bacteria are often used as decomposers and are responsible for in situ pollution repair and degradation of organic matter in ecosystems (Wei et al. 2018). Interestingly, epiphytic bacteria have obvious fermentation and nitrogen cycle functions, especially denitrification. Similar studies have reported that biofilms attached to Potamogeton crispus and Wolffia australiana are rich in nitrogen cycle species and harbor-related functional genes (Xie et al. 2015; Yan et al. 2019). The special microenvironment and microbial composition of epiphytic biofilms drive the transfer of nitrogen. Some taxonomic groups are dominant, such as specific epiphytic bacteria that are known for biofilm formation and pollutant removal, which implied the possible divergence of functional traits between epiphytic bacteria and aquatic bacteria (Xie et al. 2015). Epiphytic biofilms can uptake a large amount of nitrogen nutrients from the water column (Levi et al. 2015). The increase in nitrogen concentration will stimulate the growth of biofilms and enhance the relative abundance of nitrifying and denitrifying genera (Levi et al. 2015; Yan et al. 2018). Due to the presence of day and night alternating oxygenic-anaerobic environments in epiphytic biofilms and the presence of many aerobic denitrifying microorganisms (Sandjensen et al. 1985; Ji et al. 2015), denitrification can be accomplished on plant leaves. For instance, the dominant genus of epiphytic bacterial communities was Pseudomonas and relevant studies indicated that Pseudomonas plays an important role in circulating nitrogen elements, mineralizing organic matter, and decomposing some organic compounds (Patel et al. 2014; Ma et al. 2015). Epiphytic bacteria of submerged plants have a high denitrification rate and compose the hot zone where denitrification occurs (Yan et al. 2018; Zhao et al. 2018). Hence, the epiphytic bacteria of submerged plants may play an important role in the denitrification of lakes, especially in macrophytic lakes, where submerged plants are widely distributed. The denitrification of epiphytic bacteria contributes to the process of water de-nitride and cannot be ignored.

\section{Conclusions}

Our research indicates the following. (i) Epiphytic bacteria and planktonic bacteria have a high ratio of shared species composition, but each has some specific microbial taxa. (ii) The community structures of epiphytic bacteria and planktonic bacteria are significantly different. Aquatic environment factors have a lower explained proportion of the changes in 
epiphytic bacterial communities, indicating that the habitat microenvironment has an important influence on the construction of epiphytic bacterial communities. (iii) Epiphytic bacteria have a more prominent denitrification functions than planktonic bacteria, and the role of denitrification of epiphytic bacteria in the process of lake nitrogen removal cannot be ignored.

Funding information This project was financially supported by the National Natural Science Foundation of China (41867056), Major Project of Guizhou Province (20163022), Joint Fund of the National Natural Science Foundation of China and the Karst Science Research Center of Guizhou Province (U1812401), and Guizhou Science and Technology Plan Project (20185769).

\section{Compliance with ethical standards}

Conflict of interest The authors declare that they have no conflict of interest.

Ethical approval This article does not contain any studies performed by any of the authors with human participants.

Informed consent Informed consent was obtained from all individual participants included in the study.

\section{References}

Aßhauer KP, Wemheuer B, Daniel R, Meinicke P (2015) Tax4Fun: predicting functional profiles from metagenomic $16 \mathrm{~S}$ rRNA data. Bioinformatics 31(17):2882-2884. https://doi.org/10.1093/ bioinformatics/btv287

Battin TJ, Besemer K, Bengtsson MM, Romani AM, Packmann AI (2016) The ecology and biogeochemistry of stream biofilms. Nat Rev Microbiol 14(4):251-263. https://doi.org/10.1038/nrmicro. 2016.15

Bengtsson MM, Sjotun K, Lanzen A, Ovreas L (2012) Bacterial diversity in relation to secondary production and succession on surfaces of the kelp Laminaria hyperborea. ISME J 6(12):2188-2198. https://doi. org/10.1038/ismej.2012.67

Bing H, Zhang SH, Wang PF, Chao W (2018) Effects of water flow on submerged macrophyte-biofilm systems in constructed wetlands. Sci Rep 8(1):2650. https://doi.org/10.1038/s41598-018-21080-y

Bitrian M, González RH, Paris G, Hellingwerf KJ, Nudel CB (2013) Blue-light-dependent inhibition of twitching motility in Acinetobacter baylyi ADP1: additive involvement of three BLUFdomain-containing proteins. Microbiology 159(9):1828-1841. https://doi.org/10.1099/mic.0.069153-0

Bouletreau S, Salvo E, Lyautey E, Mastrorillo S, Garabetian F (2012) Temperature dependence of denitrification in phototrophic river biofilms. Sci Total Environ 416:323-328. https://doi.org/10.1016/j. scitotenv.2011.11.066

Burke C, Thomas T, Lewis M, Steinberg P, Kjelleberg S (2011) Composition, uniqueness and variability of the epiphytic bacterial community of the green alga Ulva australis. ISME J 5(4):590-600. https://doi.org/10.1038/ismej.2010.164

Cao T, Ni L, Xie P (2004) Acute biochemical responses of a submersed macrophyte, Potamogeton crispus L., to high ammonium in an aquarium experiment. J Freshw Ecol 19(2):279-284. https://doi. org/10.1080/02705060.2004.9664542
Cardinale BJ, Srivastava DS, Emmett Duffy J, Wright JP, Downing AL, Sankaran M, Jouseau C (2006) Effects of biodiversity on the functioning of trophic groups and ecosystems. Nature 443(7114):989992. https://doi.org/10.1038/nature05202

Cole JR, Wang Q, Fish JA, Chai B, McGarrell DM, Sun Y, Brown CT, Porras-Alfaro A, Kuske CR, Tiedje JM (2014) Ribosomal database project: data and tools for high throughput rRNA analysis. Nucleic Acids Res 42 (Database issue:D633-D642. https://doi.org/10. 1093/nar/gkt1244

Dolan JR (2005) An introduction to the biogeography of aquatic microbes. Aquat Microb Ecol 41(1):39-48. https://doi.org/10.3354/ ame 041039

Filippini M, Buesing N, Gessner MO, Bürgmann H (2009) Microbial communities in contrasting freshwater marsh microhabitats. FEMS Microbiol Ecol 69(1):84-97. https://doi.org/10.1111/j.1574-6941. 2009.00692.x

Florez JZ, Camus C, Hengst MB, Buschmann AH (2017) A functional perspective analysis of macroalgae and epiphytic bacterial community interaction. Front Microbiol 8:2561. https://doi.org/10.3389/ fmicb.2017.02561

Furey PC, Deininger A, Liess A (2016) Substratum-associated microbiota. Water Environ Res 88(10):1637-1671. https://doi.org/10.2175/ $106143016 \times 14696400495613$

Galand PE, Pereira O, Hochart C, Auguet JC, Debroas D (2018) A strong link between marine microbial community composition and function challenges the idea of functional redundancy. ISME J 12:2470 2478. https://doi.org/10.1038/s41396-018-0158-1

Garulera JB, Vila M, Borrull E, Riobó P, Franco JM, Sala MM (2016) Variability of planktonic and epiphytic vibrios in a coastal environment affected by Ostreopsis blooms. Sci Mar 80S1(S1):97-106. https://doi.org/10.3989/scimar.04405.01A

Hao B, Wu H, Cao Y, Xing W, Jeppesen E, Li W (2017) Comparison of periphyton communities on natural and artificial macrophytes with contrasting morphological structures. Freshw Biol 62(10):17831793. https://doi.org/10.1111/fwb.12991

Hassett DJ, Cuppoletti J, Trapnell B, Lymar SV, Rowe JJ, Sun Yoon S, Hilliard GM, Parvatiyar K, Kamani MC, Wozniak DJ, Hwang S-H, McDermott TR, Ochsner UA (2002) Anaerobic metabolism and quorum sensing by Pseudomonas aeruginosa biofilms in chronically infected cystic fibrosis airways: rethinking antibiotic treatment strategies and drug targets. Adv Drug Deliv Rev 54(11):1425-1443. https://doi.org/10.1016/S0169-409X(02)00152-7

He D, Ren LJ, Wu QL (2012) Epiphytic bacterial communities on two common submerged macrophytes in Taihu Lake: diversity and hostspecificity. Chin J Oceanol Limnol 30(2):237-247. https://doi.org/ 10.1007/s00343-012-1084-0

He D, Ren LJ, Wu QL (2014) Contrasting diversity of epibiotic bacteria and surrounding bacterioplankton of a common submerged macrophyte, Potamogeton crispus, in freshwater lakes. FEMS Microbiol Ecol 90(3):551-562. https://doi.org/10.1111/1574-6941.12414

Herrmann M, Saunders AM, Schramm A (2008) Archaea dominate the ammonia-oxidizing community in the rhizosphere of the freshwater macrophyte Littorella uniflora. Appl Environ Microbiol 74(10): 3279-3283. https://doi.org/10.1128/AEM.02802-07

Hörnström E (2002) Phytoplankton in 63 limed lakes in comparison with the distribution in 500 untreated lakes with varying $\mathrm{pH}$. Hydrobiologia 470(1):115-126. https://doi.org/10.1023/a: 1015619921119

Jezberová J, Jezbera J, Brandt U, Lindström ES, Langenheder S, Hahn MW (2010) Ubiquity of Polynucleobacter necessarius ssp. asymbioticus in lentic freshwater habitats of a heterogenous 2000 km2 area. Environ Microbiol 12(3):658-669. https://doi.org/10. $1111 / j .1462-2920.2009 .02106 . x$

Ji B, Yang K, Zhu L, Jiang Y, Wang HY, Zhou J, Zhang HN (2015) Aerobic denitrification: a review of important advances of the last 
30 years. Biotechnol Bioprocess Eng 20(4):643-651. https://doi. org/10.1007/s12257-015-0009-0

Jones SE, McMahon KD (2009) Species-sorting may explain an apparent minimal effect of immigration on freshwater bacterial community dynamics. Environ Microbiol 11(4):905-913. https://doi.org/10. 1111/j.1462-2920.2008.01814.x

Kasalický V, Jezbera J, Hahn MW, Šimek K (2013) The diversity of the Limnohabitans genus, an important group of freshwater bacterioplankton, by characterization of 35 isolated strains. PLoS One 8(3):e58209. https://doi.org/10.1371/journal.pone.0058209

Koo H, Strope BM, Kim EH, Shabani AM, Kumar R, Crowley MR, Andersen DT, Bej AK (2016) Draft genome sequence of Janthinobacterium $s p$. Ant5-2-1, isolated from proglacial Lake Podprudnoye in the Schirmacher oasis of East Antarctica. Genome Announcements 4(1):e01600-e01615. https://doi.org/10.1128/ genomeA.01600-15

Kuehn KA, Francoeur SN, Findlay RH, Neely RK (2014) Priming in the microbial landscape: periphytic algal stimulation of litter-associated microbial decomposers. Ecology 95(3):749-762. https://doi.org/10. 1890/13-0430.1

Kumar A, Ng DHP, Wu Y, Cao B (2018) Microbial community composition and putative biogeochemical functions in the sediment and water of tropical granite quarry lakes. Microb Ecol 77(1):1-11. https://doi.org/10.1007/s00248-018-1204-2

Kurian PS, Abraham K, Kumar PS (2012) Endophytic bacteria - do they colonize within the plant tissues if applied externally? Curr Sci 103(6):626-628 https://www.jstor.org/stable/24088792

Lachnit T, Meske D, Wahl M, Harder T, Schmitz R (2011) Epibacterial community patterns on marine macroalgae are host-specific but temporally variable. Environ Microbiol 13(3):655-665. https://doi.org/ 10.1111/j.1462-2920.2010.02371.x

Langille MG, Zaneveld J, Caporaso JG, McDonald D, Knights D, Reyes JA, Clemente JC, Burkepile DE, Vega Thurber RL, Knight R, Beiko RG, Huttenhower C (2013) Predictive functional profiling of microbial communities using 16S rRNA marker gene sequences. Nat Biotechnol 31(9):814-821. https://doi.org/10.1038/nbt.2676

Levi PS, Riis T, Alnøe AB, Peipoch M, Maetzke K, Bruus C, BaattrupPedersen A (2015) Macrophyte complexity controls nutrient uptake in lowland streams. Ecosystems 18(5):914-931. https://doi.org/10. 1007/s10021-015-9872-y

Liu JZ, Wang FW, Liu W, Tang CL, Wu CX, Wu YH (2016) Nutrient removal by up-scaling a hybrid floating treatment bed (HFTB) using plant and periphyton: from laboratory tank to polluted river. Bioresour Technol 207:142-149. https://doi.org/10.1016/j. biortech.2016.02.011

Loreau M, Naeem S, Inchausti P, Bengtsson J, Grime JP, Hector A, Hooper DU, Huston MA, Raffaelli D, Schmid B, Tilman D, Wardle DA (2001) Biodiversity and ecosystem functioning: current knowledge and future challenges. Science 294(5543):804-808. https://doi.org/10.1126/science.1064088

Louca S, Parfrey LW, Doebeli M (2016) Decoupling function and taxonomy in the global ocean microbiome. Science 353(6305):12721277. https://doi.org/10.1126/science.aaf4507

Lu HY, Wan JJ, Li JY, Shao HB, Wu YH (2016) Periphytic biofilm: a buffer for phosphorus precipitation and release between sediments and water. Chemosphere 144:2058-2064. https://doi.org/10.1016/j. chemosphere.2015.10.129

Ma Q, Qu YY, Shen WL, Zhang ZJ, Wang JW, Liu ZY, Li DX, Li HJ, Zhou JT (2015) Bacterial community compositions of coking wastewater treatment plants in steel industry revealed by Illumina highthroughput sequencing. Bioresour Technol 179:436. https://doi.org/ 10.1016/j.biortech.2014.12.041

Matu A, Lum Nde A, Oosthuizen L, Hitzeroth A, Badenhorst M, Duba L, Gidaga M, Klinck J, Kriek I-M, Lekoma PJ, Nel L, dos Ramos SM, Rossouw J, Salomane N, Segone N, Serobe S, Tiyani T, Hugo CJ, Newman JD (2019) Draft genome sequences of seven
Chryseobacterium type strains. Microbiology Resource Announcements 8(1):e01518-e01518. https://doi.org/10.1128/mra. 01518-18

Madigan MT, Martinko JM, Stahl DA, Clark DP (2005) Brock biology of microorganisms (11th ed.) Benjamin Cummings: Boston

Mori H, Maruyama F, Kato H, Toyoda A, Dozono A, Ohtsubo Y, Nagata Y, Fujiyama A, Tsuda M, Kurokawa K (2013) Design and experimental application of a novel non-degenerate universal primer set that amplifies prokaryotic $16 \mathrm{~S}$ rRNA genes with a low possibility to amplify eukaryotic rRNA genes. DNA Res 21(2):217-227. https:// doi.org/10.1093/dnares/dst052

Ordoñez OF, Lanzarotti E, Kurth D, Gorriti MF, Revale S, Cortez N, Vazquez MP, Farías ME, Turjanski AG (2013) Draft genome sequence of the polyextremophilic Exiguobacterium sp. strain S17, isolated from hyperarsenic lakes in the Argentinian Puna. Genome announcements 1(4):e00480-e00413. https://doi.org/10.1128/ genomeA.00480-13

Palmer RJ Jr, White DC (1997) Developmental biology of biofilms: implications for treatment and control. Trends Microbiol 5(11):435440. https://doi.org/10.1016/S0966-842X(97)01142-6

Parks DH, Tyson GW, Hugenholtz P, Beiko RG (2014) STAMP: statistical analysis of taxonomic and functional profiles. Bioinformatics 30(21):3123-3124. https://doi.org/10.1093/bioinformatics/btu494

Patel V, Munot H, Shouche YS, Madamwar D (2014) Response of bacterial community structure to seasonal fluctuation and anthropogenic pollution on coastal water of Alang-Sosiya ship breaking yard, Bhavnagar, India. Bioresour Technol 161:362-370. https://doi.org/ 10.1016/j.biortech.2014.03.033

Paul C, Pohnert G (2011) Production and role of volatile halogenated compounds from marine algae. Cheminform 42(21):186. https:// doi.org/10.1002/chin.201121253

Sandjensen K, Revsbech NP, Jørgensen BB (1985) Microprofiles of oxygen in epiphyte communities on submerged macrophytes. Mar Biol 89(1):55-62. https://doi.org/10.1007/BF00392877

Seymour JR, Amin SA, Raina JB, Stocker R (2017) Zooming in on the phycosphere: the ecological interface for phytoplankton-bacteria relationships. Nat Microbiol 2:17065. https://doi.org/10.1038/ nmicrobiol.2017.65

Singh S, James A, Bharose R (2017) Biological assessment of water pollution using periphyton productivity: a review. Nat Environ Pollut Technol 16(2):559-567

Song YZ, Wang JQ, Gao YX, Xie XJ (2015) The physiological responses of Vallisneria natans to epiphytic algae with the increase of $\mathrm{N}$ and $\mathrm{P}$ concentrations in water bodies. Environ Sci Pollut Res 22(11):8480 8487. https://doi.org/10.1007/s11356-014-3998-x

Su J, Kang D, Xiang W, Wu CX (2017) Periphyton biofilm development and its role in nutrient cycling in paddy microcosms. J Soils Sediments:810-819. https://doi.org/10.1007/s11368-016-1575-2

Underwood W, Melotto M, He S (2007) Role of plant stomata in bacterial invasion. Cell Microbiol 9(7):1621-1629. https://doi.org/10.1111/j. 1462-5822.2007.00938.x

Wei Z, Liu Y, Feng K, Li S, Wang S, Jin D, Zhang Y, Chen H, Yin H, Xu M, Deng Y (2018) The divergence between fungal and bacterial communities in seasonal and spatial variations of wastewater treatment plants. Sci Total Environ 628-629(1):969-978. https://doi.org/ 10.1016/j.scitotenv.2018.02.003

Wilhelm L, Singer GA, Fasching C, Battin TJ, Besemer K (2013) Microbial biodiversity in glacier-fed streams. ISME J 7(8):16511660. https://doi.org/10.1038/ismej.2013.44

Writer JH, Ryan JN, Barber LB (2011) Role of biofilms in sorptive removal of steroidal hormones and 4-nonylphenol compounds from streams. Environ Sci Technol 45(17):7275-7283. https://doi.org/10. 1021/es2008038

Wu YH, Li TL, Yang LZ (2012) Mechanisms of removing pollutants from aqueous solutions by microorganisms and their aggregates: a 
review. Bioresour Technol 107:10-18. https://doi.org/10.1016/j. biortech.2011.12.088

Wu YH, Liu JZ, Rene ER (2018) Periphytic biofilms: a promising nutrient utilization regulator in wetlands. Bioresour Technol 248:44-48. https://doi.org/10.1016/j.biortech.2017.07.081

Xie WY, Su JQ, Zhu YG (2015) Phyllosphere bacterial community of floating macrophytes in paddy soil environments as revealed by illumina high-throughput sequencing. Appl Environ Microbiol 81(2):522-532. https://doi.org/10.1128/aem.03191-14

Xu N, Tan G, Wang H, Gai X (2016) Effect of biochar additions to soil on nitrogen leaching, microbial biomass and bacterial community structure. Eur J Soil Biol 74:1-8. https://doi.org/10.1016/j.ejsobi.2016.02.004

Yan LY, Zhang SH, Lin D, Guo C, Yan LL, Wang SP, He ZL (2018) Nitrogen loading affects microbes, nitrifiers and denitrifiers attached to submerged macrophyte in constructed wetlands. Sci Total Environ 622-623:121-126. https://doi.org/10.1016/j.scitotenv. 2017.11.234
Yan L, Mu X, Han B, Zhang S, Qiu C, Ohore OE (2019) Ammonium loading disturbed the microbial food webs in biofilms attached to submersed macrophyte Vallisneria natans. Sci Total Environ 659:691-698. https://doi.org/10. 1016/j.scitotenv.2018.12.423

Zhang SH, Pang S, Wang PF, Wang C, Guo C, Addo FG, Li Y (2016) Responses of bacterial community structure and denitrifying bacteria in biofilm to submerged macrophytes and nitrate. Sci Rep 6: 36178. https://doi.org/10.1038/srep36178

Zhao YH, Xiong X, Wu CX, Xia YQ, Li JY, Wu YH (2018) Influence of light and temperature on the development and denitrification potential of periphytic biofilms. Sci Total Environ 613-614:1430-1437. https://doi.org/10.1016/j.scitotenv.2017.06.117

Publisher's note Springer Nature remains neutral with regard to jurisdictional claims in published maps and institutional affiliations. 